\title{
Does Critical Thinking Enhance EFL Learners' Receptive Skills?
}

\author{
Mohammad Reza Hashemi \\ English Department, Ferdowsi University of Mashhad, Iran \\ Email: smrhir@gmail.com \\ Reza Zabihi (Corresponding author) \\ English Department, Ferdowsi University of Mashhad, Iran \\ Email: zabihi@hotmail.com
}

\begin{abstract}
This study explored the effect of Iranian EFL learners' critical thinking abilities on their receptive English language proficiency skills. With this purpose in mind, the researchers administered the Persian version of Watson-Glaser Critical Thinking Appraisal (WGCTA) and the Interchange Objective Placement Test (Lesley, Hansen, \& Zukowski-Faust, 2005) to 96 Intermediate EFL learners, and correlated the scores obtained from the two tests to see whether there is any significant relationship between critical thinking and proficiency. Results from Pearson product-moment correlation showed significant correlations between WGCTA subscales and proficiency scores. Furthermore, while logical interpretation was the only important variable in predicting both reading and listening comprehension scores, a stepwise multiple regression consisting of Watson-Glaser subscales 1 (drawing inferences), 2 (recognizing assumptions), and 4 (logical interpretation) successfully predicted total proficiency test scores $(R=.43)$. To see to what extent total scores for critical thinking may affect English language proficiency, three groups of High, Mid, and Low were formed based on critical thinking scores. The mean proficiency scores of the three groups were compared. One-way ANOVA indicated significant differences in the mean proficiency scores among the three groups. The results of the post-hoc Scheffe test revealed that there was a significant difference between the proficiency scores of the high creative group and those of the two other groups. The implications of the results were discussed.
\end{abstract}

Index Terms — critical thinking, Watson-Glaser, listening and reading comprehension, proficiency

\section{INTRODUCTION}

Being democracy-seeking in nature, Paulo Freire's (1970) and John Dewey's (1916) views on education have inspired many scholars, researchers, and teachers who are ready to help learners have their voices heard in and out of the classroom. The 'banking' approach to education hinders learners from thinking critically by imposing on them a passive stance which makes them adaptive to the status-quo.

However, the banking concept of education has been rejected by critical pedagogues who aim at liberating students from the confines of those classrooms in which the teacher is traditionally expected to transfer knowledge to students, while students receive and accept the information, right or wrong, without deserving the right to question the authenticity of the knowledge being transferred.

Unfortunately, as Gatto (2001) puts it, schools do not let our children take an active role in community life: "School, as it was built, is an essential support system for a model of social engineering that condemns most people to be subordinate stones in a pyramid that narrows as it ascends to a terminal of control" (p. 13).

The relation of critical thinking to academic achievement had been confirmed by many researchers (e.g., Birjandi \& Bagherkazemi, 2010; Fahim, Bagherkazemi, \& Alemi, 2010; McCutcheon, Apperson, Hanson, \& Wynn, 1992; Yeh \& $\mathrm{Wu}, 1992)$. Moreover, SLA research is one area in which critical pedagogy and critical language awareness are considered by many researchers (Canagarajah, 1999; Norton \& Toohey, 2004; Pennycook, 1999, 2001; Ramanathan, 2002) to be crucial aspects of both language teaching and language learning. Thus instruction in critical thinking, which aims at achieving the ability to explore, criticize, or advocate different ideas, to reason inductively and deductively, and to infer sound conclusions from ambiguous statements (Freeley \& Steinberg, 2000), ought to be the cornerstone of second or foreign language teaching classrooms.

\section{THEORETICAL FRAMEWORK}

In the following paragraphs, the researchers briefly review the theoretical and empirical findings pertaining to critical thinking as well as its applications in general education and language learning.

A. Critical Thinking: Definition 
Critical thinking has been defined extensively; it is defined as "active, persistent, and careful consideration of any belief or supposed form of knowledge in the light of the grounds that support it and the further conclusions to which it tends" (Dewey, 1933, p. 118). It encompasses, in Pithers and Soden's (2000) words, a number of skills such as, the ability to focus the problem, uncover assumptions underlying a problem, inference, reason inductively and deductively, and judge the validity and reliability of assumptions and sources of information. As Chafee (1988, p. 29) puts it, critical thinking is "our active, purposeful, and organized efforts to make sense of our world by carefully examining our thinking, and the thinking of others, in order to clarify and improve our understanding". It also involves such important factors as interpretation, analysis, evaluation, inference, explanation, and self-regulation (Facione, 2006).

Accordingly, several scholars and researchers have made attempts to devise tests of measuring critical thinking (e.g., Facione, 1990a, 1990b; Ennis \& Millman, 1985; Ennis \& Weir, 1985; Norris \& Ennis, 1989; Norris \& King, 1984; Shipman, 1983; Ross \& Ross, 1976; Fraser, 1980; Sternberg \& Baron, 1985; Wagner, \& Harvey, 2003; Watson \& Glaser, 1980, 2006). While some of these tests such as Test on Appraising Observations (Norris \& King, 1984) measure only one aspect of critical thinking, others like the Watson-Glaser Critical Thinking Appraisal (Watson \& Glaser, 1980) cover multiple critical thinking abilities. This latter test, comprising five subsections, is one of the most reliable and valid measures of critical thinking (Gadzella \& Baloglu, 2003; McKown, 1997), and had been employed by many researchers (e.g., Birjandi \& Bagherkazemi, 2010; Fahim et al., 2010; Ghaemi \& Taherian, 2011; Loftspring, 2006; McCutcheon et al., 1992).

\section{B. Critical Thinking in Education}

From an educational perspective, there is a general agreement among scholars and researchers on the importance of raising students' critical awareness in schools and in the classroom many of whom have found significant relationships between critical thinking and academic achievement (e.g., Frisby, 1992; Giancarlo \& Facione, 2001; Jacobs, 1995; King, Wood, \& Mines, 1990; Kokinda, 1989; Mines, King, Hood, \& Wood, 1990; McCutcheon et al., 1992; Nelson, 1994; Tsui, 2002; Villavicencio, 2011; Yeh \& Wu, 1992).

Jacobs (1995), for example, made use of the California Critical Thinking Skills Test (CCTST) in order to examine the role of critical thinking in private university students' scores on the Student Aptitude Test (SAT). The results indicated that CCTST scores were strongly related to students' verbal intelligence as measured by the SAT. In another study, Villavicencio (2011) studied the relationship between critical thinking and achievement among two hundred and twenty engineering students. It was found that critical thinking was significantly positively correlated with students' final grades. Moreover, Yeh and Wu (1992) investigated the relationship between critical thinking and elementary and secondary school students' academic achievement. They employed the Cornell Critical Thinking Test, Level X (CCT-X) for measuring critical thinking, and found that scores from this test correlated significantly with students' total achievement scores. In a similar vein, McCutcheon et al. (1992) explored the relationship between critical thinking skills and academic achievement among sixty psychology students. The results of their study revealed that two subscales of Watson-Glaser Critical Thinking Appraisal (WGCTA), i.e. the ability to draw valid inferences and the ability to weigh and interpret evidence, were predictive of higher achievement scores. In her attempts to find out the relationship between critical thinking abilities and academic achievement among forty-nine nursing students, Kokinda (1989) used the Watson-Glaser Critical Thinking Appraisal as a valid measure of critical thinking, correlated the scores obtained from this test with students' achievement, and found significant results. Although most of the studies have highlighted significant results regarding the effect of critical thinking on academic achievement, there are studies such as the one conducted by Azar (2010) which have found no significant relationship between the two variables.

\section{Critical Thinking in Language Learning}

When it comes to language learning, particularly learning English as a second or foreign language, where a combination of historical, social, cultural, and political issues is involved, the necessity of working on critical thinking among ESL/EFL learners is more severely felt, and needs to be equally highlighted by lesson planners, materials developers, teacher educators, and teachers.

With this in mind, it is unfortunate that only a few studies (e.g., Birjandi \& Bagherkazemi, 2010; Fahim et al., 2010; Ghaemi \& Taherian, 2011) had been conducted so far to throw some light on the importance of critical thinking in English language classes. Birjandi and Bagherkazemi (2010), for example, examined the relationship between the critical thinking ability of English language teachers and their success in teaching as measured by the Successful Iranian EFL Teacher Questionnaire (SIETQ). They found out that three subscales of the Watson-Glaser Critical Thinking Appraisal, i.e. drawing inferences, interpreting evidence, and evaluating arguments were predictive of about $50 \%$ of higher teacher success. In a similar vein, Ghaemi and Taherian (2011), having employed the same instruments, found a significant relationship between EFL teachers' critical thinking and their professional success. In another study, Fahim et al. (2010) investigated the relationship between eighty-three EFL learners' performances on the Watson-Glaser Critical Thinking Appraisal and the reading module of TOEFL. The participants were in advanced 3 and 4 levels. The researchers found that learners' scores on the reading test increased significantly with their scores on the WGCTA.

Such issues, to the researchers' best knowledge, have not yet been sufficiently approached by SLA researchers. In their attempts to initiate research on such issues, the researchers undertook the present study in order to determine to 
what extent successful performance on the listening and reading comprehension sections of the Interchange Objective Placement Test is contingent upon learners' critical thinking ability.

\section{PuRPOSE OF THE STUdY}

Given what was said above concerning the importance of critical thinking and its ignorance by professionals in ELT profession, the present study was undertaken to uncover the extent to which the critical thinking ability of EFL learners may enhance, or hinder, their reading and listening comprehension. The following questions and null hypotheses were thus put forth:

\section{A. Research Questions}

Q1: Is there any significant relationship between critical thinking subscales and learners' listening comprehension?

Q2: Do critical thinking subscales affect learners' reading comprehension?

Q3: Does the total score for critical thinking affect learners' English language proficiency?

\section{B. Null Hypotheses}

HO1: There is no significant relationship between Iranian EFL learners' critical thinking skills and their listening comprehension ability.

HO2: There is no significant relationship between Iranian EFL learners' critical thinking skills and their reading comprehension ability.

HO3: There is no significant relationship between Iranian EFL learners' total score for critical thinking and their English language proficiency.

\section{METHOD}

\section{A. Participants}

Ninety-six female Intermediate EFL learners from a variety of academic backgrounds took part in the study. They were selected from five private language institutes in Mashhad, a city in north-eastern Iran (The Iran Language Institute, Jahad-e daneshgahi Institute, Khalaghan-e-Javan Institute, Kish Language Institute, and Ferdowsi Language Institute). These institutes were selected because they were among the most creditable private language institutes in Mashhad. Having assured learners of the confidentiality of the results, the researchers selected the subjects based on their agreement to take part in the study. The participants ranged in age from 15 to 38 years old (mean $=19.51$, standard deviation $=4.88$ ), and varied in their English language learning experience from 18 months to 7 years.

\section{B. Instruments}

Two instruments were employed in the present study:

Firstly, the Persian version of Watson-Glaser Critical Thinking Appraisal, Form A (WGCTA-FA) was used for measuring critical thinking. The test encompasses five subsections, namely drawing inferences, recognizing assumptions, making deductions, interpreting evidence, and evaluating arguments, each comprising 16 items with two to five alternatives. The appraisal is not subject-specific and can be completed in 60 minutes. The test-retest reliability of the original appraisal $(r=0.81)$ has been reported by Watson and Glaser $(1980)$, and the reliability coefficient of its Persian adaptation has been estimated by Cronbach's Alpha $(\alpha=0.85)$ in Faravani (2006). A composite score for the five subscales of the test is obtained with values varying from 0 to 80 . In the present study, Cronbach Alpha estimated the reliability of the whole items as 0.76 .

Secondly, the Interchange Objective Placement Test was employed to test learners' listening and reading comprehension, and also language use. It is a 70-item multiple-choice test, designed by Lesley, Hansen, and ZukowskiFaust (2005), and primarily measures the receptive skills, i.e. listening and reading, and grammar components. The test consists of three sections: listening (20 items), reading (20 items), and language use (30 items). The administration of and answering the Objective Test requires 50 minutes. The Listening items assess learners' ability to understand main idea, context, and supporting details in a conversation, as well as the speaker's intent. The Reading questions, likewise, measure learners' ability to understand main and supporting ideas in written passages, vocabulary, and also the author's intent. Moreover, the Language Use section investigates learners' ability in recognizing contextually appropriate and grammatically correct statements. As Lesley, Hansen, and Zukowski-Faust (2005, p. 5) have pointed out, "the different components of the test may be administered to individuals or to groups, and in any order". In the present study, the researchers have utilized the total Objective Placement Test containing three subcomponents of proficiency, i.e. listening comprehension, reading comprehension, and language use.

\section{Procedures}

The two instruments mentioned above were distributed among 96 EFL learners. The administration phase occurred during class hours by prior arrangement with the instructors. The instruments were submitted to the learners who were asked not to mention their names on the answer sheets; rather, in order to receive reliable scores on critical thinking and proficiency, the tests were coded numerically. Since the WGCTA was in Persian, no questions were expected to be 
raised by the participants; however, the researchers were present in all administration sessions and encouraged the participants to raise whatever questions they had.

The data gathered from the two tests were analyzed by utilizing the Statistical Package for Social Sciences (SPSS) version 16.0. To examine the normality of the distribution, descriptive statistics was employed. To investigate the role of critical thinking in learners' English proficiency scores, Pearson product-moment correlation was applied to the data. To find out to what extent the five subscales of critical thinking might have predictive power in learners' English language proficiency subcomponents (listening, reading, and language use), multiple regression analysis was run. Finally, in order to compare the effect of total critical thinking scores on total proficiency scores among low, mid, and high critical thinkers, Levene's test of variance homogeneity, One-way ANOVA, and the post-hoc Scheffe test were conducted, respectively.

\section{RESULTS}

Table 1 summarizes the descriptive results of WGCTA and the Objective Placement Test subscales. As can be seen in the table, the participants' scores ranged from 5 to 56 on WGCTA-FA with a mean score of $42(\mathrm{M}=42.2)$, and from 14 to 65 with a mean score of $44(M=44.68)$ on the Objective Test.

TABLE 1.

MEANS AND STANDARD DEVIATIONS OF WGCTA AND PROFICIENCY

\begin{tabular}{|l|l|l|l|l|l|l|}
\hline & N & \# of items & Min & Max & Mean & Std. Deviation \\
\hline WGCTA subscales & & & & & & \\
\hline Drawing inferences & 96 & 16 & 0 & 10 & 5.02 & 2.542 \\
\hline Recognizing assumptions & 96 & 16 & 0 & 14 & 9.91 & 3.071 \\
\hline Argument evaluation & 96 & 16 & 0 & 14 & 9.17 & 3.018 \\
\hline Deductive reasoning & 96 & 16 & 0 & 14 & 9.41 & 2.834 \\
\hline Logical interpretation & 96 & 16 & 0 & 13 & 8.73 & 2.654 \\
\hline Total critical thinking scores & 96 & 80 & 5 & 56 & 42.23 & 11.243 \\
\hline Proficiency subscales & & & & & & \\
\hline Listening & 94 & 20 & 0 & 20 & 13.66 & 3.993 \\
\hline Reading & 94 & 20 & 4 & 20 & 12.83 & 3.795 \\
\hline Language use & 94 & 30 & 7 & 30 & 18.12 & 4.355 \\
\hline Total proficiency scores & 94 & 70 & 14 & 65 & 44.68 & 9.448 \\
\hline Valid N (listwise) & 94 & & & & & \\
\hline
\end{tabular}

To examine whether there are significant correlations between learners' critical thinking and their proficiency, Pearson product-moment correlation was applied to the data. The results revealed that the total score for proficiency was significantly and positively correlated with Drawing inferences $(r=0.271, \mathrm{p}<0.01)$, Argument evaluation $(\mathrm{r}=$ $0.255, \mathrm{p}<0.05)$, Deductive reasoning $(\mathrm{r}=0.263, \mathrm{p}<0.05)$, and Logical interpretation $(\mathrm{r}=0.325, \mathrm{p}<0.01)$. However, no significant relationship was found between proficiency and Recognizing assumptions ( $p>0.05$ ) (see Table 2).

TABLE 2.

CORRELATIONS BETWEEN CRITICAL THINKING SUBSCALES AND ENGLISH PROFICIENCY

\begin{tabular}{|l|l|}
\hline & Proficiency \\
\hline Drawing inferences & $0.271^{* *}$ \\
\hline Recognizing assumptions & 0.053 \\
\hline Argument evaluation & $0.255^{*}$ \\
\hline Deductive reasoning & $0.263^{*}$ \\
\hline Logical interpretation & $0.325^{* *}$ \\
\hline
\end{tabular}

** Shows the existence of significant relationship at the level of 0.01

* Shows the existence of significant relationship at the level of 0.05

Furthermore, the researchers conducted the regression analysis with a Stepwise method to see whether and to what extent critical thinking can predict learners' proficiency scores. The results reveal which variables are important in predicting English language proficiency. Logical interpretation was the only important variable in predicting both reading comprehension $(\mathrm{R}=.28)$ and listening comprehension $(\mathrm{R}=.22)$ scores. Total scores for English proficiency explained $16 \%$ of the total variance, (Adjusted $\mathrm{R}^{2}=0.16, \mathrm{p}<.05$ ) using a combination of Logical interpretation, Drawing inferences, and Recognizing assumptions. Logical interpretation was the best predictor for proficiency scores (Adjusted $\mathrm{R}^{2}=0.09, \mathrm{p}<.05$ ), indicating that high scorers in Logical interpretation received higher grades on the proficiency test. On the other hand, recognizing assumptions subscale was the best predictor of lower grades on the proficiency test. Table 4 presents the results for English proficiency being regressed on the variables of interest in this study (WGCTA subscales). 
TABLE 3.

REGRESSION ANALYSIS FOR CRITICAL THINKING SUBSCALES AND ENGLSIH PROFICIENCY SUBCOMPONENTS

\begin{tabular}{|c|c|c|c|c|c|c|}
\hline Predictors & $\mathbf{R}$ & $\mathbf{R}^{\mathbf{2}}$ & Adjusted R ${ }^{2}$ & $\mathbf{F}$ & $\mathbf{P}$ & $\boldsymbol{B}$ \\
\hline \multicolumn{7}{|l|}{ Total proficiency scores } \\
\hline Logical interpretation & 0.325 & 0.106 & 0.096 & 10.884 & 0.00 & 0.421 \\
\hline Drawing inferences & 0.381 & 0.146 & 0.127 & 7.749 & 0.01 & 0.255 \\
\hline Recognizing assumptions & 0.438 & 0.192 & 0.165 & 7.120 & 0.02 & -0.270 \\
\hline \multicolumn{7}{|l|}{ Listening comprehension } \\
\hline Logical interpretation & 0.222 & 0.049 & 0.039 & 4.747 & 0.03 & 0.222 \\
\hline \multicolumn{7}{|l|}{ Reading comprehension } \\
\hline Logical interpretation & 0.284 & 0.081 & 0.071 & 8.083 & 0.00 & 0.284 \\
\hline
\end{tabular}

From a statistical perspective, the assumption behind the null hypothesis is that there is no significant correlation between Iranian EFL teachers' critical thinking ability and their proficiency. To test this hypothesis, Pearson product moment correlation was run. Table 4 depicts the coefficients of this correlation between total WGCTA and proficiency scores. The calculated correlation coefficient is 0.331 which is significant at 0.01 level of significance $(r=0.331, p<$ 0.01). Put it another way, the two variables at issue are significantly positively correlated with each other and, thus, the null hypothesis is rejected.

TABLE 4 .

CORRELATION BETWEEN TOTAL WGCTA AND ENGLSIH PROFICIENCY SCORES

\begin{tabular}{|l|l|}
\hline Total critical thinking & Proficiency \\
\hline \multirow{2}{*}{$* *$ Shows the existence of significant relationship at the level of 0.01}
\end{tabular}

To further analyze the data, a One-way ANOVA was conducted so that the researchers could compare the effect of critical thinking on English proficiency among low, mid, and high critical thinkers. Prior to conducting One-way ANOVA, however, Levene's test, which assesses variance homogeneity in different samples, was employed. As can be seen in Table 5, Levene's test indicated equal variances $(p>0.05)$, hence the appropriateness of conducting a parametric test such as ANOVA.

TABLE 5 .

LEVENE'S TEST OF VARIANCE HOMOGENEITY

\begin{tabular}{|l|l|l|l|}
\hline Levene's statistics & df1 & df2 & Sig. \\
\hline 0.467 & 2 & 89 & 0.629 \\
\hline
\end{tabular}

The results from One-way ANOVA revealed that proficiency differed significantly across the three subgroups of critical thinking: $\mathrm{F}(2,89)=7.57, \mathrm{p}<0.05$. In other words, the main effect of critical thinking on English language proficiency is significant. Table 6 presents the results of One-way ANOVA for low, mid, and high levels of critical thinking and proficiency.

TABLE 6.

THE RESULTS OF ONE-WAY ANOVA FOR LEVELS OF CRITICAL THINKING AND PROFICIENCY

\begin{tabular}{|l|l|l|l|l|l|}
\hline & Sum of Squares & df & Mean Square & F & Sig. \\
\hline Between Groups & 1145.008 & 2 & 572.504 & 7.573 & .001 \\
\hline Within Groups & 6728.209 & 89 & 75.598 & & \\
\hline Total & 7873.217 & 91 & & & \\
\hline
\end{tabular}

In the light of the above, the researcher used a post hoc comparison of means in order to locate the differences among means. To this end, Scheffe test, which allows very powerful testing of grouped means against other grouped means, was used. The results of the post-hoc Scheffe test indicated that, at the level of 0.05 , there was no significant difference between the proficiency scores of the two low and mid critical thinking groups. However, the difference between the proficiency scores of the high group and those of the two other groups was significant in such a way that the proficiency scores of the high group were greater than those of the mid and low groups (Table 7).

TABLE 7.

THE RESULTS OF POST-HOC SCHEFFE TEST FOR PROFICIENCY

\begin{tabular}{|l|l|l|l|}
\hline \multirow{2}{*}{} & \multirow{2}{*}{$\mathbf{N}$} & Subset for alpha $=\mathbf{. 0 5}$ & $\mathbf{2}$ \\
\cline { 3 - 4 } & & $\mathbf{1}$ & \\
\hline low & 26 & 40.92 & 49.55 \\
\hline mid & 35 & 43.54 & 1.000 \\
\hline high & 31 & & .506 \\
\hline Sig. & & & \\
\hline
\end{tabular}

\section{DISCUSSION}


Placement tests have always functioned as one of the most demanding gate keepers to a myriad of workplaces and academic institutions in the majority of countries. Their growing significance calls for an investigation into the way such tests and their different sections are allied with cognitive notions of current interest in psychology and in language pedagogy. One such notion is the ability to think critically. The present study was conducted to see if there was a statistically significant relationship between EFL learners' critical thinking ability and their performance on the Interchange Objective Placement Test. The results of the study are discussed below.

\section{A. The Relationship between Critical Thinking and Learners' English Proficiency}

The results of Pearson product-moment correlation showed significant and positive correlations between the total score for proficiency and four subscales of WGCTA: Drawing inferences, Argument evaluation, Deductive reasoning, and Logical interpretation. Although no significant correlation was found between proficiency and Recognizing assumptions ( $\mathrm{p}>0.05$ ), it can be strongly claimed by the researcher that critical thinking is a crucial factor in explaining EFL learners' high proficiency levels. This finding is quite in line with that obtained by Fahim et al. (2010), and similar to those obtained in other studies (Kokinda, 1989; McCutcheon et al., 1992; Villavicencio, 2011; Yeh \& Wu, 1992).

\section{B. Prediction of English Language Proficiency Subcomponents by Critical Thinking}

The predictive power of critical thinking subscales for English language proficiency was gauged by conducting the regression analysis the results of which were indicative of predicting $16 \%$ of the variances in proficiency scores by a combination of Logical interpretation, Drawing inferences, and Recognizing assumptions (Table 3). While the Recognizing assumptions subscale was predictive of lower grades on the Objective Test, the Logical interpretation subscale was the best predictor for proficiency scores, indicating that high scorers in Logical interpretation received higher grades on the proficiency test. It was also the sole predictor of the listening and the reading subcomponents of the Interchange Objective Placement Test. Therefore, Logical interpretation, which refers to interpreting evidence to decide if conclusions are legitimate or not, may be of prime importance for developing receptive skills like listening and reading.

\section{The Role of Total Critical Thinking Scores in English Language Proficiency}

Having conducted the correlation analysis, the researchers found a significant relationship $(\mathrm{p}<0.01)$ between total scores for critical thinking and learners' English proficiency scores. In addition, the results of One-way ANOVA and Post-Hoc Scheffe test revealed the three groups of learners classified based on their critical thinking scores, namely, High Critical thinking, Mid Critical thinking, and Low Critical thinking learners, demonstrated different levels of proficiency. In other words, the high critical thinking group enjoyed higher proficiency scores than the mid and low critical thinking counterparts. This finding is similar to those found in other studies in which critical thinking proved to be an important correlate of academic performance (e.g., McCutcheon et al., 1992; Villavicencio, 2011; Yeh \& Wu, 1992), and quite in line with Fahim et al. (2010) who concluded that there is a direct relationship between critical thinking and the scores on the reading module of TOEFL. Therefore, not paying enough attention to critical thinking in foreign language classes, in turn, may lead to children's inability of obtaining excellence in English proficiency required of them to be able to perform well in placement situations.

The present study has some useful implications for classroom instruction. Since critical thinking skills can be developed and taught (Halpern, 1993; McKown, 1997), and due to the findings of the present study and those of the other studies mentioned above, it is suggested that critical thinking be developed as a core academic skill so that multiple educational outcomes are accomplished by learners. As far as English language classrooms are concerned, critical thinking can be enhanced through teachers' manipulation and mediation of learners' cognitive abilities. This may simply be accomplished, for example, by asking challenging questions which raise learners' critical awareness. Fisher (2003, cited in Jarvis, 2005) suggests seven types of questions that can stimulate critical thinking: Context, temporal order, particular events, intentions, choices, meaning (meta-discourse message), and telling. As a case in point, 'debate' is an essential activity which presupposes freedom of speech as one of the preconditions for the investigation of and judgment about contemporary problems. However, granting learners freedom of speech in every way possible may disturb classroom environment which is often characterized as emphasizing discipline and obedience on the part of learners. This may be even more evident in foreign language classes where a confluence of cultural, social, biological, personality, contextual, and racial factors are involved.

\section{REFERENCES}

[1] Azar, A. (2010). The effect of critical thinking dispositions on students achievement in selection and placement exam for university in Turkey. Journal of Turkish Science Education, 7 (1), 61-73.

[2] Birjandi, P., \& Bagherkazemi, M. (2010). The relationship between Iranian EFL teachers' critical thinking ability and their professional success. English Language Teaching, 3 (2), 135-145.

[3] Canagarajah, A. S. (1999). Resisting linguistic imperialism in English teaching. Oxford: Oxford University.

[4] Chaffee, J. (1988). Thinking critically. Boston, MA, Houghton Mifflin.

[5] Dewey, J. (1916). Democracy and education: An introduction to the philosophy of education. New York: Macmillan. 
[6] Dewey, J. (1933). How we think: A restatement of the relation of reflective thinking to the educative process. Boston: D.C. Heath.

[7] Ennis, R.H. \& Millman, J. (1985). Cornell Critical Thinking Test-Level X. Pacific Grove, CA: Midwest Publications.

[8] Ennis, R.H. \& Weir, E. (1985). The Ennis-Weir essay test: An instrument for testing and teaching. Midwest Publications: Pacific Grove, CA.

[9] Facione, P. (1990a). The California Critical Thinking Skills Test-college level technical report 1: Experimental validation and content validity. California Academic Press, Millbrae, CA.

[10] Facione, P. (1990b). The California Critical Thinking Skills Test-college level technical report 2: Factors predictive of critical thinking skills. California Academic Press, Millbrae, CA.

[11] Facione, P. (2006). Critical thinking: What it is and why it counts. California: California Academic Press.

[12] Fahim, M., Bagherkazemi, M., \& Alemi, M. (2010). The relationship between test takers' critical thinking ability and their performance on the reading section of TOEFL. Journal of Language Teaching and Research, 1 (6), 830-837.

[13] Faravani (2006). Portfolio and critical thinking. Unpublished M.A. Thesis. Iran: Ferdowsi University of Mashhad.

[14] Fraser, B. J. (1980). Development and validation of a test of enquiry skills. Journal of Research in Science Teaching, 17, 7-16.

[15] Freeley, A. J. \& Steinberg, D.L. (2000). Argumentation and debate: Critical thinking for reasoned decision making. (10 ${ }^{\text {th }}$ ed.). Wadsworth: Thomson Learning.

[16] Freire, P. (1970). Pedagogy of the oppressed. New York: The Seabury Press.

[17] Frisby, C. L. (1992). Construct validity and psychometric properties of the Cornell Critical Thinking Test (Level Z): A contrasted group analysis. Psychological Reports, 71, 291-303.

[18] Gadzella, B. M., \& Baloglu, M. (2003). Psychometric properties of Watson-Glaser Critical Thinking Appraisal for a sample of education majors. Psychol Rep, 92 (3), 1249-1254.

[19] Gatto, J. (2001). The seven-lesson schoolteacher, rereading America: Cultural contexts for critical thinking and writing. Boston, MA.

[20] Ghaemi, H., \& Taherian, R. (2011). The role of critical thinking in EFL teachers' teaching success. MJAL, 3 (1), 8-22.

[21] Giancarlo, C. A., \& Facione, P. A. (2001). A Look across four years at the disposition toward critical thinking among undergraduate students. The Journal of General Education, 50 (1), 29-55.

[22] Halpern, D. (1993). Assessing the effectiveness of critical thinking instruction. The Journal of General Education, 42, $239-254$.

[23] Jacobs, S. S. (1995). Technical characteristics and some correlates of the California critical thinking skills test forms A and B. Higher Education Research, 36, 89-108.

[24] Jarvis, M. (2005). The psychology of effective learning and teaching. London: Nelson Thornes Ltd.

[25] King, P. M., Wood, P. K., \& Mines, R. A. (1990). Critical thinking among college and graduate students. Review of Higher Education, 13 (3), 167-186.

[26] Kokinda, M. A. (1989). The measurement of critical thinking skills in a selected baccalaureate nursing program. Dissertations available from ProQuest. Paper AAI9004798. http://repository.upenn.edu/dissertations/AAI9004798

[27] Lesley, T., Hansen, C., \& Zukowski-Faust, J. (2005). Interchange passages: Placement and evaluation package. Cambridge: Cambridge University Press.

[28] Loftspring, R.G. (2006). The relationship of years of experience and level of education to critical thinking skills of physical therapists (Doctoral Dissertation, University of Cincinnati, 2006).

[29] McCutcheon, L. E., Apperson, J. M., Hanson, E., \& Wynn, V. (1992). Relationships among critical thinking skills, academic achievement, and misconceptions about psychology. Psychological Reports, 71, 635-639.

[30] McKown, L. K. (1997). Improving leadership through better decision making: Fostering critical thinking. A research paper presented to the Research Department of Air Command and Staff College. Retrieved from http://www.au.af.mil/au/awc/awcgate/acsc/97-0506.pdf

[31] Mines, R. A., King, P. M., Hood, A. B., \& Wood, P. K. (1990). Stages of intellectual development and associated critical thinking skills in college students. Journal of College Students Developments, 31, 537-547.

[32] Nelson, C. E. (1994). Critical thinking and collaborative learning: in K. Boswald, S. J. Hamilton (eds.) Collaborative learning: Underlying processes and effective techniques. New directions for teaching and learning \#59: Jossey Bass Higher Education and Adult Education Series: San Francisco, CA.

[33] Norris, S.P., \& Ennis, R.H. (1989). Evaluating critical thinking. Pacific Grove, CA: Midwest.

[34] Norris, S.P., \& King, R. (1984). The design of a critical thinking test on appraising observations. Institute for Educational Research and Development, Memorial University of Newfoundland, St. Johns, Newfoundland.

[35] Norton, B., \& Toohey, K. (2004). Critical pedagogies and language learning. Cambridge: Cambridge University Press.

[36] Pennycook, A. (1999). Introduction: Critical approaches to TESOL. TESOL Quarterly, 33 (3), 329-348.

[37] Pennycook, A. (2001). Critical applied linguistics: A critical introduction. Mahwah, NJ: Lawrence Erlbaum Associates.

[38] Pithers, R. T., \& Soden, R. (2000). Critical thinking in education: A review. Educational Research, 42 (3), $237-249$.

[39] Ramanathan, V. (2002). The politics of TESOL education. New York: Routledge Falmer/Taylor \& Francis.

[40] Ross, J. D., \& Ross, C. M. (1976). Ross test of higher cognitive processes. Novato, CA: Academic Therapy Publications.

[41] Shipman, V.C. (1983). The New Jersey test of reasoning skills. Totowa, N.J: Slosson.

[42] Sternberg, R.J., \& Baron, J.B. (1985). A statewide approach to measuring critical thinking skills. Educational Leadership, 43, 40-43.

[43] Tsui, L. (2002). Fostering critical thinking through effective pedagogy: Evidence from four institutional case studies. The Journal of Higher Education, 73 (6), 740-763.

[44] Villavicencio, F. T. (2011). Critical thinking, negative academic emotions, and achievement: A meditational analysis. The AsiaPacific Education Researcher, 20 (1), 118-126.

[45] Wagner, T. A., \& Harvey, R. J. (2003). Developing a new critical thinking test using item response theory. Paper presented at the 2003 annual conference of the Society for Industrial and Organizational Psychology. Retrieved June 11, 2008, from http://harvey.psyc.vt.edu/Documents/WagnerHarveySIOP2003.pdf 
[46] Watson, G. B., \& Glaser, E. M. (1980). WGCTA Watson-Glaser critical thinking appraisal manual: Forms A and B. San Antonio: The Psychological Corporation.

[47] Watson, G., \& Glaser, E. M. (2006). Watson-Glaser critical thinking appraisal short form manual. San Antonio, TX: Harcourt.

[48] Yeh, Y., \& Wu, J. (1992). The relationship between critical thinking and academic achievement among elementary and secondary school students. Journal of Education and Psychology, 15, 79-100.

Mohammad Reza Hashemi is assistant professor in Applied Linguistics. He is currently at Ferdowsi University of Mashhad, Iran, where he teaches translation studies. His areas of interest include translation studies, discourse analysis, and CDA.

Reza Zabihi holds an MA in TEFL obtained from Ferdowsi University of Mashhad, Iran. His major research interests include sociolinguistic and psycholinguistic studies, and technology-based English teaching. 